\title{
Characterization of the Causal Organism of Soft Rot of Tomatoes and Other Vegetables and Evaluation of Its Most Aggressive Isolates
}

\author{
Asma Akbar1, Musharaf Ahmad1, Azra², Neelam³ , Sana Zeb Khan4, Zahoor Ahmad5,6* \\ ${ }^{1}$ Department of Plant Pathology, The University of Agriculture, Peshawar, Pakistan \\ ${ }^{2}$ Department of Plant Pathology, Amir Muhammad Khan Campus, Mardan, Pakistan \\ ${ }^{3}$ Department of Biochemistry, The University of Agriculture, Peshawar, Pakistan \\ ${ }^{4}$ Department of Plant Protection, The University of Agriculture, Peshawar, Pakistan \\ ${ }^{5}$ Department of Plant Pathology, College of Plant Science and Technology and the Key Lab of Crop Disease \\ Monitoring \& Safety Control in Hubei Province, Huazhong Agricultural University, Wuhan, China \\ ${ }^{6}$ Department of Adaptive Research, Quetta, Balochistan, Pakistan \\ Email: ${ }^{*}$ hoor30@yahoo.com
}

Received 28 December 2014; accepted 1 March 2015; published 3 March 2015

Copyright (C) 2015 by authors and Scientific Research Publishing Inc.

This work is licensed under the Creative Commons Attribution International License (CC BY).

http://creativecommons.org/licenses/by/4.0/

(c) (i) Open Access

\section{Abstract}

To isolate the causal organism of soft rot of vegetables, diseased samples of potato, tomato, carrot, chilies, and bell pepper, were analyzed in the lab, using nutrient agar (NA) and/or the enrichment host (Bell pepper) technique. Successful isolations were purified by sub-culturing, identified as Erwinia carotovora subsp. carotovora through biochemical tests and their pathogenicity was confirmed through inoculation on green tomato fruits. The isolates were tested for their aggressiveness to find out the most aggressive one in terms of producing maximum soft rot on tomatoes. CRD (completely randomized design), with four replication was used and data were analyzed using LSD (least significant test) test. Among the five isolates evaluated for aggressiveness on tomato fruits, chili isolate was found to be the most aggressive followed by tomato and potato isolates producing $22.3 \mathrm{~mm}, 7.9 \mathrm{~mm}$, and $7.8 \mathrm{~mm}$ diameter soft rot lesions, respectively.

\section{Keywords}

Aggressiveness, Bio-Chemical Tests, Erwinia carotovora, Pathogencity, Soft Rot of Tomatoes

\footnotetext{
${ }^{*}$ Corresponding author.
} 


\section{Introduction}

Tomato (Lycopersicum esculentum Mill) is an important greenhouse and field-grown vegetable with a production of 529.9 million tonnes in Pakistan [1]. Tomatoes contribute to a healthy, well-balanced diet and are believed to be beneficial for the heart among other organs. They are rich in minerals, vitamins, essential amino acids, sugar and dietary fibers. They have many varieties and are consumed fresh as salads or cooked in sauces, soup and meat or fish dishes. They can process into juices and ketchup. Yellow tomatoes have higher vitamin A content than red tomatoes, but the red tomatoes contain lycopene, one of the most powerful natural antioxidants and especially in cooked tomatoes, and have been found to prevent against carcinogenic substances. They have also been shown to improve the skin's ability to protect against harmful UV rays. Natural genetic variation in tomatoes and their wild relatives has given a genetic treasure of genes that produce lycopene, carotene, anthocyanin, and other antioxidants [2].

Tomatoes are attacked by many kinds of pathogens such as fungi, nematodes, bacteria, viruses and viroids. Among bacterial diseases, the soft rottening bacteria of genus Erwinia are very important. The genus Erwinia has a lot of species and subspecies such as amylovora, aphidicola, billingiae, carotovora, chrysantum, mallotivora, papayae, persicina, psidii, pyrifoliae, rhapontici, toletana, tracheiphila, carotovora subsp. atroseptica, carotovora subsp. betavasculorum, Erwinia carotovora subsp. carotovora (Ecc), Erwinia carotovora subsp. odorifera, and Erwinia carotovora subsp. wasabiae [3]. Among these, Erwinia carotovora subsp. carotovora (Ecc) causes soft rot diseases in many economically important crops such as tomato and others horitcultural crops [4].

Ecc is a Gram-negative bacterium that lives alone or aggregates in pairs and chains. Non-spore forming and peritrichously flagellated, it is a facultative anaerobe that is catalase negative and oxidase positive, and produces a number of extracellular plant cell wall degrading enzymes such as pectic enzymes that degrade pectin, cellulase that degrades cellulose, hemicellulases, arabanases, cyanoses and a protease. A major problem in agriculture, the microbes ceaselessly invade crops of potatoes and other vegetables in the fields or in storage that cause plant tissues to become soft and watery which eventually turn slimy and foul-smelling [5].

As far as research work on bacterial diseases including soft rot of tomatoes and other vegetables is concerned, detailed research needs to be done on different aspects of the disease. One important aspect of research that needs to be undertaken is the characterization studies. Characterization of a pathogen helps us understand it better which in turn helps us to find better control strategies against the pathogen. The present study was an attempt to characterize the locally isolated pathogen and find the difference in aggressiveness among the isolates of Erwinia carotovora subsp. carotovora obtained from different hosts.

\section{Materials and Methods}

\subsection{Isolation and Culture Conditions}

Infected samples of potato, carrots, tomato, and peppers were collected from local markets, cleaned, surface sterilized with $0.5 \%$ sodium hypochlorite solution (for a few seconds), washed with sterile distilled water, and then ground in sterile $0.85 \%$ saline solution using sterile mortar under aseptic conditions [6]. The resulting bacterial suspension was left undisturbed for a few minutes. This suspension was then streaked on the surface of plates containing nutrient agar (NA), and the plates were incubated at $30^{\circ} \mathrm{C}$ for $24 \mathrm{~h}$. Individual colonies growing on NA were picked up, and streaked on nutrient agar (NA) plates again, and then incubated at $30^{\circ} \mathrm{C}$ for another 24 h. This was repeated several times to obtain pure cultures.

Nutrient agar is a non-selective medium and sometimes there is a problem of over growth of unrelated and saprophytic bacteria on this medium. Therefore in order to overcome this problem, sometime green pepper fruits were used as enrichment hosts for the soft rot Erwinia which were subsequently isolated on nutrient agar. For this purpose, sterile toothpicks were first stabbed in diseased tissues and then stabbed in green peppers. The inoculated peppers were then placed in plastic bags along with moist tissue pepper and incubated at $30^{\circ} \mathrm{C}$ for 24 hours. The resulting soft rotten peppers were used for isolation of the bacterium as described before.

\subsection{Identification and Characterization}

Identification was carried out using biochemical tests specific for the genus Erwinia subsp. carotovora as described by [7]-[9]. Different biochemical tests included, $\mathrm{KOH}$ test, catalase test, tolerance to 5\% NaCl, anaerob- 
ic growth, mucoid growth, yellow pigment on YDC, sensitivity to erythromycin, growth at $37^{\circ} \mathrm{C}$ [10] [11].

\section{3. $\mathrm{KOH} \mathrm{(3 \% )} \mathrm{Test}$}

Fresh solution of $3 \%$ potassium hydroxide $(\mathrm{KOH})$ was prepared and then a drop of this solution was placed on regular microscopic slide. A 24-hour old bacterial culture was placed in this drop and mixed for 10 seconds (Figure 1(b)). Bacterial suspension making strands when lifted up by tooth pick were considered gram negative. Production of a watery suspension (no viscous strands when lifted up) indicates gram positive result [12]. This test was performed for each isolate.

\subsection{Catalase Test}

A drop of hydrogen peroxide $\left(\mathrm{H}_{2} \mathrm{O}_{2}\right)$ was placed on a slide, and bacterial cell was mixed with this drop $\left(\mathrm{H}_{2} \mathrm{O}_{2}\right)$. Production of gas bubbles indicated positive reaction while no bubbles (control).

\subsection{Tolerance to $5 \% \mathrm{NaCl}$}

For this test, nutrient agar medium was prepared with $5 \% \mathrm{NaCl}$. The medium was inoculated with bacterial

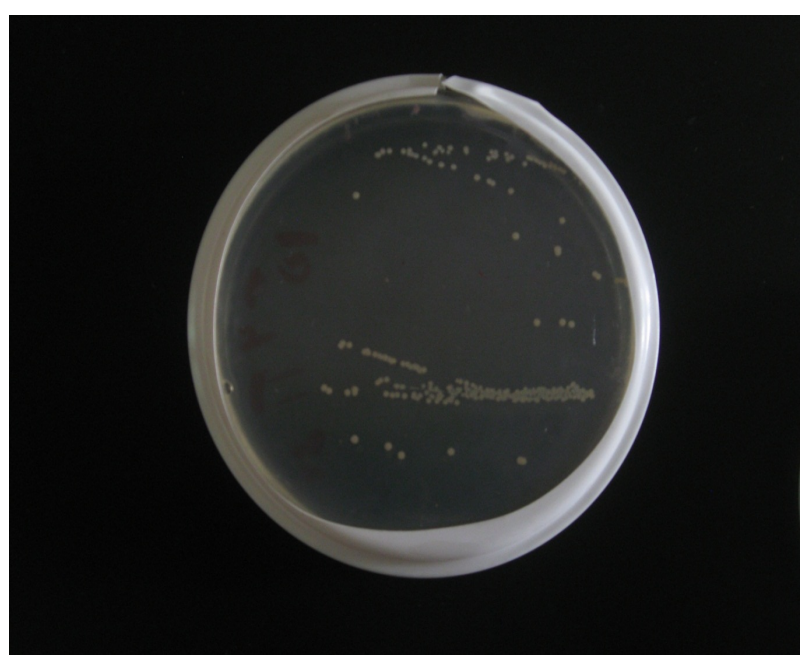

(a)

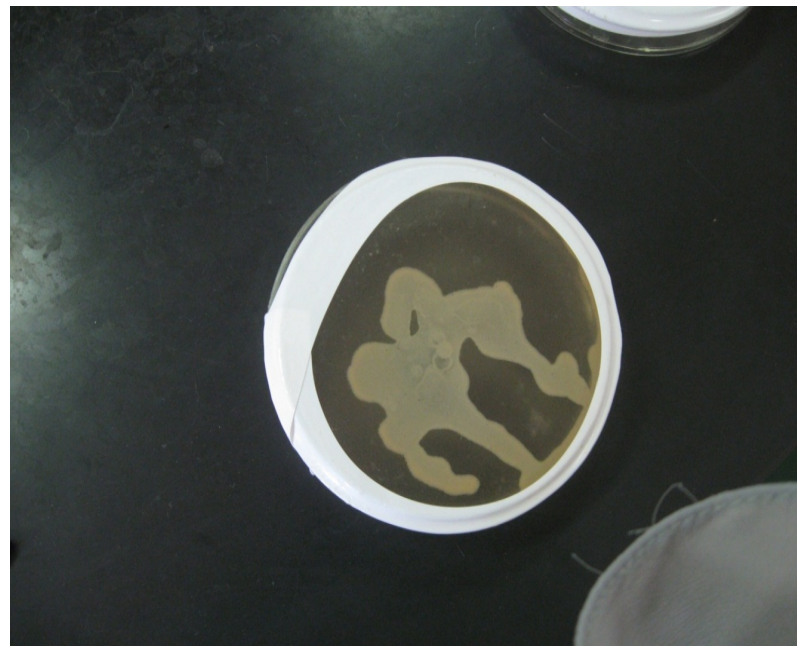

(c)

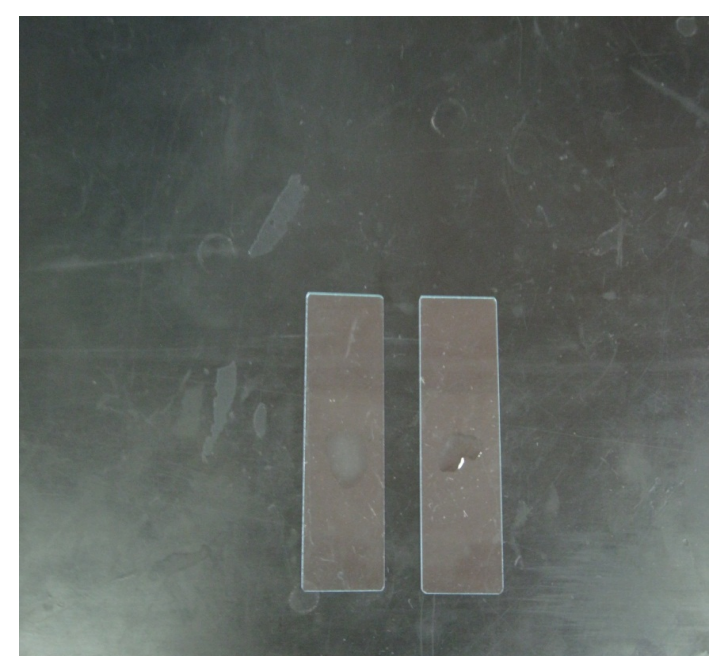

(b)

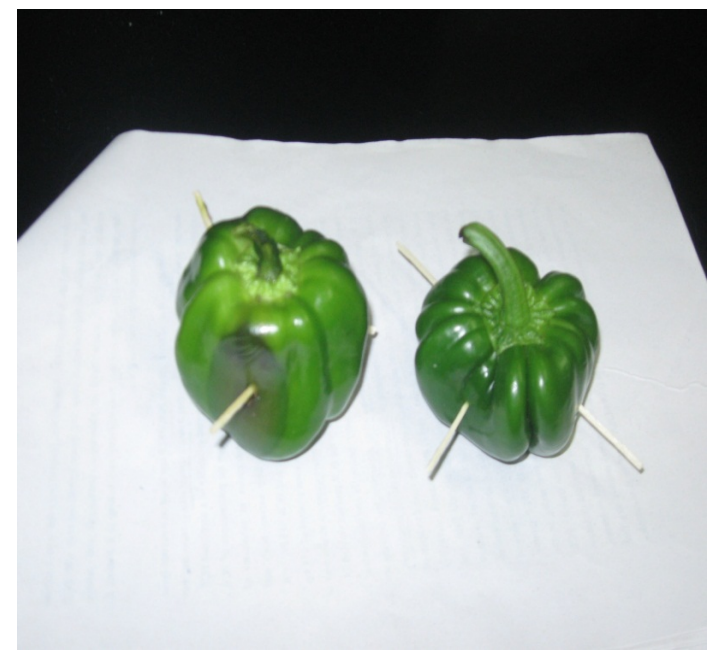

(d)

Figure 1. Characterization of Erwinia carovotovra subsp. carotovora isolates obtained from different hosts. (a) Individual colonies; (b) KOH Test; (c) Mucoid growth; (d) Enrichment host for E. carovotovra. 
isolates, and the inoculated plates were incubated at $27^{\circ} \mathrm{C}$ for 24 hours. Growth of isolates on this medium was considered as salt tolerance. On plates used for control there was no growth.

\subsection{Anaerobic Growth}

Nutrient agar (NA) medium was prepared, poured in test tubes (5 ml per test tube), which were then covered and sterilized at $121^{\circ} \mathrm{C}$ and 15 pound/square inch pressure for 20 minutes. Following sterilization, the test tubes containing the medium were left undisturbed in laminar flow unit to cool down and were stab-inoculated with cultures. For each isolate separate test tube was used. Un-inoculated tubes served as control. The top of the medium inside test tubes was covered with liquid paraffin to avoid aerobic condition and incubated at $27^{\circ} \mathrm{C}$ for 48 hours. Culture showing any growth on the medium was considered positive for anaerobic growth.

\subsection{Mucoid Growth}

Plates containing LB medium were inoculated with bacterial isolates and then incubated at $27^{\circ} \mathrm{C}$ for $24-48$ hours. Production of excessive slime on this medium was considered mucoid, which was obvious when colonies were picked with a toothpick (Figure 1(c)).

\subsection{Yellow Pigment on YDC}

YDC (Yeast Dextrose Calcium Carbonate) medium was prepared (yeast extract $10 \mathrm{~g}$, calcium carbonate $20.0 \mathrm{gm}$, dextrose $20 \mathrm{gm}$, agar $15 \mathrm{gm}$, distilled water 1 liter) sterilized for 15 minutes at $121^{\circ} \mathrm{C}$ and then after pouring in Petri dishes, following solidification, was spot inoculated with 24 hours old cultures. The inoculated plates were labeled, sealed and incubated for 24 hours at $27^{\circ} \mathrm{C}$. Production of yellow colonies on this medium was considered as a positive result, in comparison with control.

\subsection{Sensitivity to Erythromycin}

One liter modified LB medium (Bactotrypton; 10.0 g, Bacto yeast extract, 5 g; Nacl, 10 g; Agar, 15 g) was prepared; of which $25 \mathrm{ml}$ dispensed in 5 small test tube ( $5 \mathrm{ml}$ per test tube). The rest of medium (in flask) and test tubes were covered with aluminum foil and sterilized in autoclave at $121^{\circ} \mathrm{C}$ for 20 minutes. After sterilization the medium was poured into Petri dishes and left for solidification. This medium is called basal layer. The small test tubes were still left in autoclave to avoid solidification. After solidification of the basal layer, liquid medium (a little cooled but not solidified) was inoculated with $200 \mu \mathrm{l}$ of the bacterial suspension $\left(10^{8} \mathrm{cfu} / \mathrm{ml}\right)$. The $5 \mathrm{ml}$ of the inoculated medium in the test tubes were poured on the top of the basal layer in each Petri plate, gently spread and allowed to solidify. This top layer along with basal layer is called seed layer. Commercially available antibiotic discs containing erythromycin $(15 \mu \mathrm{g} / \mathrm{disc})$ were aseptically placed on the surface of the seed layer (one disc in the middle of each Petri dish). Plates were incubated at $27^{\circ} \mathrm{C}$ for 48 hours. A zone of inhibition around the disc was recorded in mm for each isolate [13].

\subsection{Growth at $37^{\circ} \mathrm{C}$}

To find out whether the isolates are Eca, Ecc or Ech (Ecc and Ech can grow at higher temperature but Eca cannot) nutrient agar plates were streaked with the bacterial isolates. The plates were incubated at $37^{\circ} \mathrm{C}$ for 24 hours along with a control. Growth of bacteria indicated positive results.

\subsection{Relative Aggressiveness/Pathogencity on Tomato Fruits}

All isolates were tested for pathogenicity on tomato (Lycopersicum esculentum). Purified colonies were used for pathogenicity tests on green tomato fruit using CRD (completely randomized design), with four replication [11]. Tooth pick Inoculated tomato fruits were put in plastic bag along with wet tissue paper. Bags were stapled and incubated at $30^{\circ} \mathrm{C}$ for $24-48$ hours (Figure $1(\mathrm{~d})$ ). Soft rot lesions were measured in mm. Colonies that gave positive results were saved in $70 \%$ glycerol solution $(0.5 \mathrm{ml}$ of bacterial suspension was added to $0.5 \mathrm{ml}$ of sterile glycerol solution) and stored at $-20^{\circ} \mathrm{C}$ or $-80^{\circ} \mathrm{C}$. Cultures were also preserved in $0.85 \%$ sterile saline solution and stored at $4^{\circ} \mathrm{C}$. 


\section{Results and Discussion}

\subsection{Identification and Characterization of the Isolates}

The isolates were identified based on disease symptoms, pathogenicity tests, colony morphology and biochemical tests. The colonies obtained on nutrient agar were morphologically transparent, circular, raised, shiny and creamy white after 28 hours incubation at $27^{\circ} \mathrm{C}$. All of the five isolates were able to grow under anaerobic conditions, were tolerant to $5 \% \mathrm{NaCl}$; (sodium chloride), catalase positive, gram negative and produced yellow pigment on YDC medium.

Moreover, the isolates were able to grow at $37^{\circ} \mathrm{C}$ and were not sensitive to erythromycin (Table 1). The last two tests (i.e. growth at 37c and sensitivity to erythromycin) are specific to Ecc isolates [13]. The results were compared with those of [8] [14].

The results of general biochemical test, such as an-aerobic growth, yellow pigment on YDC, salt tolerance etc., confirmed our bacterial isolates as Erwinia spp. To find out whether or not the isolates were Ecc, and to characterize them accordingly key diagnostic tests such as growth at $37^{\circ} \mathrm{C}$ and sensitivity to erythromycin were performed. The ability of these isolates to grow at $37^{\circ} \mathrm{C}$ and their non-sensitivity to erythromycin indicated that they were Ecc and not Eca or Ech. Eca usually cannot grow at $37^{\circ} \mathrm{C}$ and Ech is sensitivity to erythromycin [14].

One of these isolates was weakly sensitive to erythromycin (potato isolate). This is not unusual because some bacterial strains of the same species give variable results [10] [15] found their Eca and Ecc strains to be insensitive to erythromycin but [14] presented conflicting report that their Eca and Ecc strains were sensitive to this antibiotic.

\subsection{Aggressiveness Test on Tomato Fruit}

All E. carotovora subsp. carotovora isolates were tested for their aggressiveness on green tomato fruits. The results presented in (Table 2 and Figure 2), showed that among the different isolates there were significant $(\mathrm{P} \leq$ 0.05 ) variations regarding their abilities to cause soft rot on green tomato fruits. All the isolates were pathogenic and caused varying degrees of soft rot. Chilies isolate caused maximum rotting followed by tomato and potato isolates.

Table 1. Characterization of Erwinia carotovora subsp. carotovora isolates obtained from different hosts.

\begin{tabular}{|c|c|c|c|c|c|c|c|c|}
\hline Isolate \# & $\begin{array}{c}\text { Anaerobic } \\
\text { growth }\end{array}$ & $\begin{array}{l}5 \% \mathrm{NaCl} \\
\text { tolerance }\end{array}$ & $\begin{array}{c}\text { Catalase } \\
\text { test }\end{array}$ & $\begin{array}{l}\text { 3\% KOH test } \\
\text { (Gram reaction) }\end{array}$ & $\begin{array}{l}\text { Mucoid } \\
\text { growth }\end{array}$ & $\begin{array}{c}\text { Yellow pigment } \\
\text { on YDC }\end{array}$ & $\begin{array}{l}\text { Sensitivity to } \\
\text { erythromycin }\end{array}$ & $\begin{array}{l}\text { Growth } \\
\text { at } 37^{\circ} \mathrm{C}\end{array}$ \\
\hline Isolate 1 (potato) & + & + & + & - & + & + & - & + \\
\hline Isolate 2 (chilies) & + & + & + & - & ++ & + & \pm & + \\
\hline Isolate 3 (tomato) & + & + & + & - & + & + & - & + \\
\hline Isolate 4 (carrot) & + & + & + & - & + & + & - & + \\
\hline Isolate 5 (bell pepper) & + & + & + & - & + & + & - & + \\
\hline
\end{tabular}

$+=$ positive,$-=$ negative, $++=$ strongly positive, $\pm=$ variable result.

Table 2. In vitro aggressiveness (mm) of Erwinia carotovora subsp. carotovora isolates on green tomato fruits.

\begin{tabular}{ccc}
\hline S. No. & Source & Means (soft rot mm) \\
\hline 1 & Potato & $7.83 \mathrm{~B}$ \\
2 & Tomato & $7.9 \mathrm{~B}$ \\
3 & Chilies & $22.3 \mathrm{~A}$ \\
4 & Carrot & $2.83 \mathrm{D}$ \\
5 & Bell paper & $6.3 \mathrm{BC}$ \\
6 & Control & $0.00 \mathrm{D}$ \\
\hline
\end{tabular}

LSD = 3.559. Means followed by same letter(s) do not significantly $(\mathrm{P} \leq 0.05)$ differ from each other. 


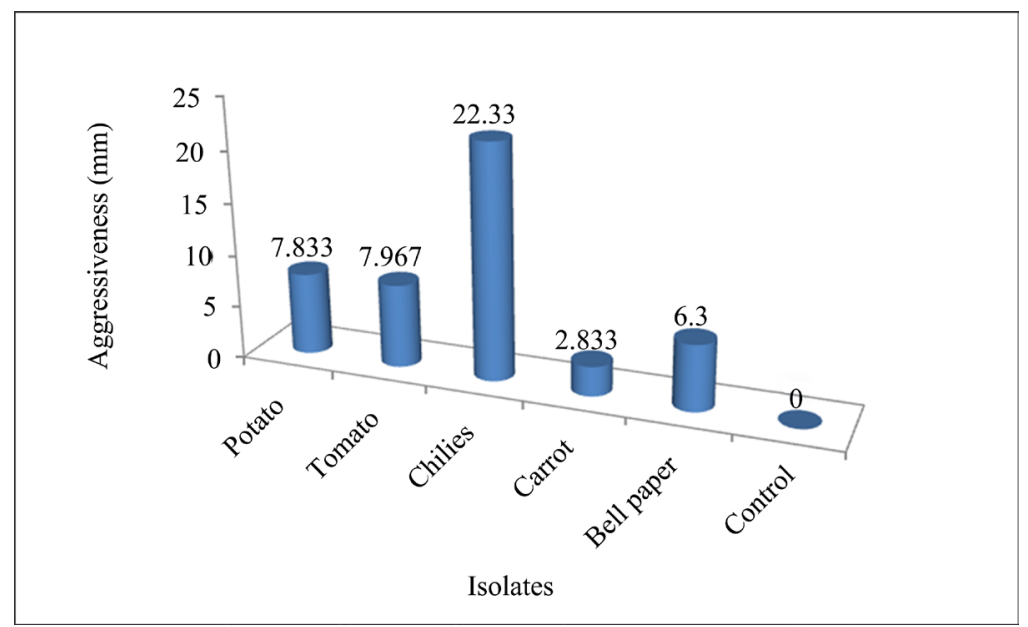

Figure 2. In vitro aggressiveness (mm) of Erwinia carotovora subsp. carotovora isolates on green tomato fruits.

All of the isolates were pathogenic when healthy hosts were inoculated. However the degree of pathogencity was significantly different $(\mathrm{P} \leq 0.05)$ when tested on tomato fruits. Tomato isolate was expected to cause maximum rotting yet Chili isolate proved to be more aggressive. The result suggests that Ecc strains do not exhibit host specificity, instead the pathogen has a general host range. These results were in line with those of [16], showed that significant difference $(\mathrm{P} \leq 0.05)$ were found among the strains for aggressiveness on tuber but the relative aggressiveness in one host was not always associated with aggressiveness or pathogenicity in other host.

\section{Conclusion and Recommendations}

Biochemical test, such as an-aerobic growth, yellow pigment on YDC, and salt tolerance, confirmed our bacterial isolates as Erwinia spp. and the species specific tests confirmed our isolates as Ecc. It was also concluded that Ecc strains did not exhibit host specificity. Instead, the pathogen had a general host range. It is recommended that whenever there is the Ecc problem, crop rotation should include grain crops rather than fleshy vegetables in order to reduce the amount of Ecc primary inoculum.

\section{References}

[1] MINFAL (2011-2012) Agricultural Statistics of Pakistan 2012. Ministry of Food, Agric. \& Livest. Govt. of Pakistan, Islamabad.

[2] Wihelm, S., Ulrine, H., Sheilawise, O. and Hagen, T. (2001) Dietary Tomato Paste Protect against Skin Diseases and Ultraviolet Light. Journal of Nutrition, 131, 1449-1451.

[3] Eozeby, J.P. (1997) List of Bacterial Names with Standing in Nomenclature: A Folder Available on the Internet. International Journal of Systematic Bacteriology, 47, 590-592. http://dx.doi.org/10.1099/00207713-47-2-590

[4] Costa, A.B., Eloy, M., Cruz, L., Janse, J.D. and Oliveira, H. (2006) Studies on Pectolytic Erwinia spp. in Portugal Reveal Unusual Strains of E. carotovora Subsp. Atroseptica. Journal of Plant Pathology, 88, 161-169.

[5] Wood, M. (1998) Ubi7-New Tool for Potato Breeders. Agricultural Research, 46, 12-13.

[6] Schaad, N.W. (1980) Laboratory Guide for Identification of Plant Pathogenic. Bacteria Amer Phytopathol Society Minnual.

[7] Dye D.W. (1969) A Taxonomic Study of the Genus Erwinia. II. The “Carotovora” Group. New Zealand Journal of Science, 12, 81-97.

[8] Lelliott, R.A. and Dickey, R.S. (1984) Erwinia. In: Krieg, N.R. and Holt, J.G., Eds., Bergey’s Manual of Systematic Bacteriology, Phytopathology Journal, 1, 469-476.

[9] Lelliott, R.A. and Stead, D.E. (1987) Methods for the Diagnosis Bacterial Diseases of Plants. In: Preece, T.F., Ed., Methods in Plant Pathology, Blackwell Scientific Publications, Oxford.

[10] Klement, Z., Mavridis, A., Rudolf, K., Vidaver, A., Perombelon, M.C.M. and Moore, L.W. (1990) Inoculation of Plant Tissues. Phytopathology Journal, 47, 98-112. 
[11] Seo, S.T., Furuya, N., Lim, C.K., Takanami, Y. and Tsuchiya, K. (2002) Phenotypic and Genetic Diversity of Erwinia carotovora ssp. carotovora Strains from Asia. Journal of Phytopathology, 150, 120-127. http://dx.doi.org/10.1046/j.1439-0434.2002.00722.x

[12] NCBI (2007) National Center for Biotechnology Information. www.ncbi.nlm.nih.gov/RefSeq/publications.html

[13] Dickey, R.S. and Kelman, A. (1988) Erwinia carotovora or Soft Rot Group. In: Schaad, N.W., Ed., Laboratory Guide for Identification of Plant Pathogenic Bacteria, American Phytopathological Society, St. Paul, 44-59.

[14] Perombelon, M.C.M. and Kelman, A. (1980) Ecology of the Soft Rot Erwinias. Annual Review of Phytopathology, 18, 361-387.

[15] El-Hendawy, H.H., Osman, M.E. and Ramadan, H.A. (2002) Pectic Enzymes Produced in Vitro and in Vivo by Erwinia spp. Isolated from Carrot and Pepper in Egypt. Journal of Phytopathology, 150, 431-438. http://dx.doi.org/10.1046/j.1439-0434.2002.00780.x

[16] Smith, C. and Bartz, J.A. (1990) Variation in the Pathogenicity and Aggressiveness of Strains of Erwinia carotovora Subsp. carotovora Isolated from Different Hosts. Plant Diseases, 74, 505-509. http://dx.doi.org/10.1094/PD-74-0505 